\title{
Modelling factors of influence on business process management in the organizations of the clothing industry
}

DOI: $10.35530 / I T .072 .05 .1816$

\begin{abstract}
REZUMAT
Modelling factors of influence on business process management in the organizations of the clothing industry

Business process management (BPM) in organizations of the clothing industry can be considered as a practice of importance for establishing a stable and progressive business. In contemporary business, which considers the application of best business practices within production-business systems, effective process management becomes important and emerges as a practice that contributes to the overall improvement of the organization's operations. BPM focuses on improving both internal and inter-organizational operations that take place between organizations within the supply chain of clothing industry. The effective BPM in the organizations of the clothing industry may depend on the establishment of the various elements. The assumption is that influential elements are specifics of the garment industry such as the primary BPM activities, the different dimensions of BPM which are consistent with a comprehensive view of this approach, as well as the mere involvement of human resources in the business processes of the organizations. The defined influential elements are treated as variables of the structural model, created by the implementation of the IBM SPSS AMOS structural modelling program, exploring a number of hypothesized impacts. The results of this research help to understanding the impact of these elements on the strengthening BPM practice in the clothing industry organizations.
\end{abstract}

Keywords: business process management (BPM), clothing industry, BPM dimensions, process management activities, human resources in clothing industry processes

Modelarea factorilor de influență asupra managementului proceselor de afaceri în organizațiile din industria de îmbrăcăminte

Managementul proceselor de afaceri (BPM) în organizațiile din industria de îmbrăcăminte poate fi considerat o practică importantă, pentru stabilirea unei afaceri stabile și în evoluție. În mediul de afaceri contemporan, care are în vedere aplicarea celor mai bune practici de afaceri în cadrul sistemelor de producție-afaceri, gestionarea eficientă a proceselor devine importantă și apare ca o modalitate de îmbunătățire generală a operațiunilor organizației. BPM se concentrează atât pe îmbunătățirea operațiunilor interne, cât și a celor inter-organizaționale, care au loc între organizațiile din lanțul de aprovizionare al industriei de îmbrăcăminte. Un BPM eficient în organizațiile din industria de îmbrăcăminte poate depinde de stabilirea diferitelor elemente. Presupunerea este că elementele influente sunt specificul industriei de îmbrăcăminte, cum ar fi activitățile primare BPM, diferitele dimensiuni ale BPM care sunt în concordanță cu o viziune cuprinzătoare a acestei abordări, precum și simpla implicare a resurselor umane în procesele de afaceri ale organizațiilor. Elementele influente definite sunt tratate ca variabile ale modelului structural, create prin implementarea programului de modelare structurală IBM SPSS AMOS, explorând o serie de modele de impact ipotetice. Rezultatele acestei cercetări ajută la înțelegerea impactului acestor elemente asupra consolidării practicii BPM în organizațiile din industria de îmbrăcăminte.

Cuvinte-cheie: managementul proceselor de afaceri (BPM), industria de îmbrăcăminte, dimensiunile BPM, activități de gestionare a proceselor, resurse umane în procesele din industria de îmbrăcăminte

\section{INTRODUCTION}

Under the influence of contemporary business conditions organizations of the clothing industry have the task to harmonize their business with the new market demands and to find the best business practice which will provide their success. Each industrial branch is characterized by specific working conditions [1]. As Mareš [2] states, each industrial branch is specific in its own way in accordance with the production processes carried out within it.

Clothing industry is specific in terms of various issues. This research takes into account the intensity of work within the manufacturing processes of the clothing industry [3], the predominant presence of the female workforce in the workforce structure of the clothing industry [4], and predominant participation of micro, small and medium-sized enterprises [5] in the structure of companies engaged in the production of apparel. These characteristics reflect to the business processes within clothing and textile industry organizations, and the quality of the functioning of business processes can contribute to competitive advantage strengthening, in contemporary business conditions $[6,7]$. 
Business processes represent the base of every business, and, accordingly, the formation of best business practices based on business process management (BPM) is justified [8]. Fleacă and Purcărea [9] state that any organization within the textile and apparel industry has three basic business process groups, namely: (1) the manufacturing process group, (2) the new garment product development process group, and, (3) the marketing process group. In accordance with these processes, it is necessary to determine the activities within the different process dimensions that, based on the nature of the process, are primary to achieve the improvement and development of the business of the clothing industry organizations. It has been known for a long time that human resources play a central role in the implementation and supervision of the functioning of business processes [10].

Consequently, this research focuses on the specific aspects of the clothing industry, the dimensions of BPM, and the primary activities of BPM in accordance with the specific characteristics of the clothing industry. The study also investigates the role of human resources as an element that significantly influence the success of BPM, and, finally, the creation of promising business practices for clothing industry organizations based on BPM.

The main objective of this paper is to examine the impact of factors that potentially might influence the adoption of best business practices within the clothing industry organizations through BPM. The first, theoretical part of the paper, accordingly, highlights and reviews aforementioned aspects in more detailed way. In the remaining, second part of the paper, the modelling approach of the assumed impacts is described and explained on the basis of gathered data.

\section{FACTORS OF INFLUENCE ON THE BPM IN THE CLOTHING INDUSTRY}

Clothing and textile industry represent resourceintensive as much as labour-intensive industry branches in which many production tasks, based on human work, are difficult to replace by automatic production [11, 12]. Taking the tailoring process as an example, one can see the need for the presence of human resources possessing specific knowledge and skills. Although a large number of solutions based on the application of Computerized Numerical Control (CNC) textile cutting technology have been developed, the cutting process is carried out manually in a large number of enterprises, especially micro and small ones $[13,14]$. Although it is possible to create cut-outs using computers, in practice, manual work is still present in the tasks of creating, constructing, modelling, grading and fitting cut-outs [15, 16]. Dimitrijevic et al. [17] state that small and medium-sized enterprises (SMEs) must respond to contemporary challenges by modernizing production processes and achieving competitiveness, with labour expertise being considered as one of the influential factors. The female workforce has a significant share in the workforce structure of the clothing industry, which is cited as a characteristic of labour-intensive activities [18, 19]. These specific features appear as a starting point of a potential influence on BPM.

The processes represent a series of interconnected activities with clearly defined inputs and outputs [20]. A series of interconnected, structured tasks enables the creation of specific products or services and describes how organizations conduct their business $[21,22]$. Their flexibility depends on human resources, decisions made and the level of expertise [23]. Within labour-intensive industries, such as the clothing industry, the role of human resources in the realization of business processes is particularly prominent. Sustainable business processes are performed by people, who, in turn, tend to find out a balance between learning from the past, experimenting and adapting to the future [24]. Process efficiency is, among other things, reflected in the adaptation of process skills, roles and activities [25]. Therefore, the next factor whose impact needs to be explored is the importance of human resources in managing the business processes of the garment industry.

Within the spectrum of different levels of managerial decision making, business process design is the primary step of managing business processes and has traditionally been considered a strategic issue [26]. Organizations within the textile and clothing industries need to be aware of the need to perform welldefined processes [27]. BPM contributes to improving organizational efficiency through standardization of activities and processes [28]. In today's business environment, all organizations try to achieve business efficiency and effectiveness that will allow them to be more innovative, flexible and successful, however, each organization, in accordance with the industry in which it operates, is specific in its own way, and one universal way of managing business processes will not contribute to the achievement of this aspiration of organizations [29, 30]. Accordingly, it is necessary to carry out a set of specific activities that will ensure the application of best business practice in BPM, and determining the primary BPM activities is another potentially influential factor.

BPM is established through dimensions such as human resource management, development of process-based information systems, focus on consumers and competitors, process structures, performance measurement and improvement of business processes, processes in supplier relations, process organizational culture, alignment of process and strategic goals and process identification, documentation, and standardization. These dimensions are the result of a holistic view of BPM issues [31], and, reasonably, they are considered as the fourth factor whose impact should be examined within the research part of the paper. 


\section{RESEARCH METHODOLOGY}

Factors of potential influence on the BPM in the clothing industry, defined in the theoretical part of the work, are modelled in the research part of the work for the purpose of assessing their real impact, based on the responses of 508 respondents working in different organizations of the clothing industry.

Respondents' answers were collected with the help of a questionnaire, that was created and relied on the literature sources [22, 32-36], with some modifications. Respondents rated the claims on a 5-point Likert scale, with 1 indicating absolute disagreement with the claim presented, and 5 indicating absolute agreement of employees. The data collected in this way were coded and a database was formed within the software package for statistical processing of data SPSS 20. Table 1 shows the indicators used to test the hypothesized impacts within the model for assessing the impact of defined elements on BPM in clothing industry organizations.

The first step in the research part of the study is to identify basic characteristics of the sample by applying descriptive statistics analysis. The next step involves conducting a test of reliability of indicators within the variables included in the model. The reliability test is performed based on the Cronbach's Alpha coefficient calculation. Descriptive statistics analysis and Cronbach's Alpha coefficient calculation are performed within the SPSS program. Finally, structural modelling of assumed factors is performed using IBM SPSS AMOS package v23, which makes it possible to test the effects of defined components and draw conclusions about the functioning of BPM practices within the clothing industry based on the responses of employees of such organizations.

\section{Defining potential impacts and research hypotheses}

The assumption in this research is that the specific aspects of the clothing industry affect the different dimensions of BPM, and that these aspects influence through the BPM dimensions the quality of BPM. Specific features can also influence the application of primary BPM activities in the clothing industry organizations and human resources in the clothing industry BPM. The following hypotheses are formed: Specific aspects of clothing industry influence different BPM dimensions $(\mathrm{H} 1)$; Specific aspects of clothing industry have a significant impact on establishment of effective BPM over the impact of the BPM dimensions $(\mathrm{H} 2)$; Specific aspects of clothing industry stimulate the application of primary BPM activities in clothing industry (H3); and, Specific aspects of clothing industry achieve the influence on reactions and perceptions of human resources about BPM in clothing industry $(\mathrm{H} 4)$.

In many similar studies, relating the subject of this research, there is a claim that BPM activities shape the quality, flexibility and efficiency of BPM initiatives [37]. The assumption is also that the primary activities of the clothing industry BPM can influence the perceptions and behaviors of humans performing certain process roles within the clothing industry process, the establishment of dimensions of BPM, and the quality of the BPM system itself. Therefore, the following additional hypotheses are formulated: Primary BPM activities of the clothing industry influence perceptions and behaviors of employees about BPM of clothing industry (H5); Primary BPM activities of the clothing industry influence the establishment of BPM dimensions ( $\mathrm{H6})$; and, Primary BPM activities of the clothing industry stimulate the establishment of effective BPM (H7).

Finally, an understanding of the processes and overall human resource management system can have a

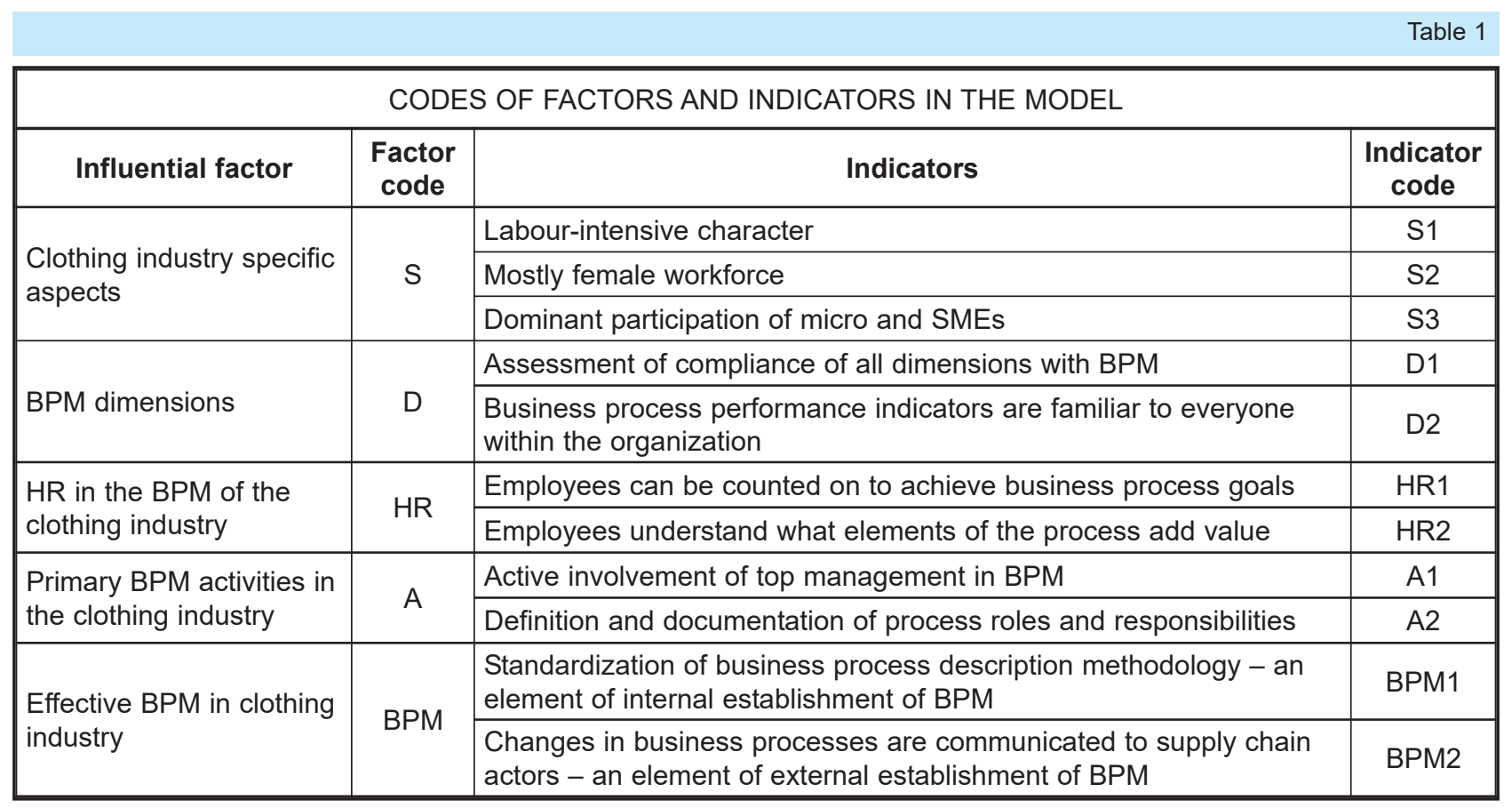




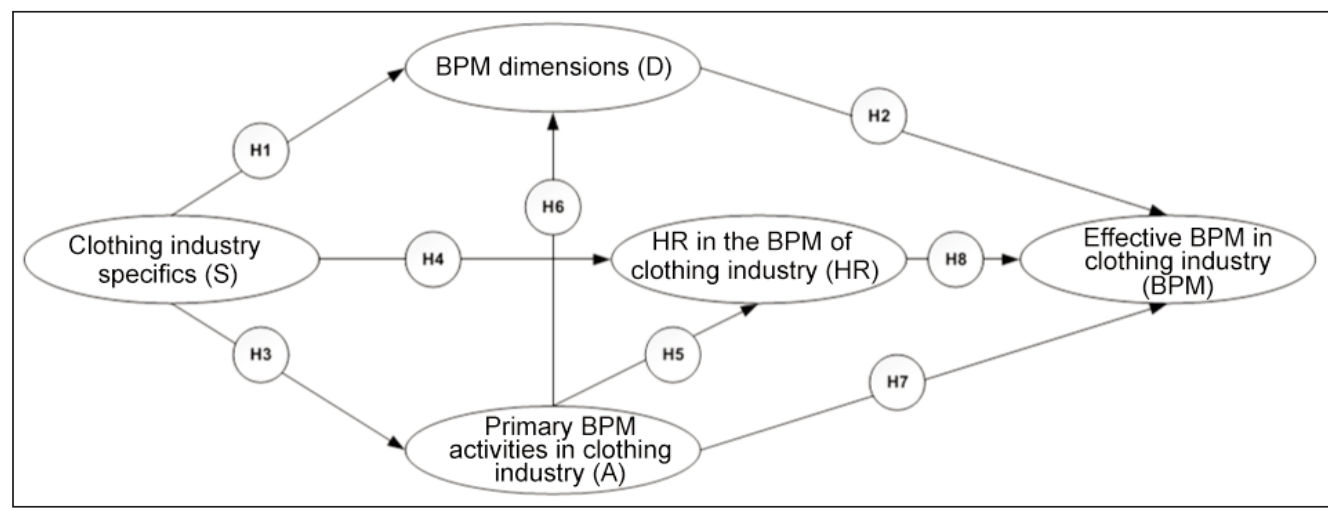

Fig. 1. Conceptual model of the research ment for testing defined hypotheses. It is possible, therefore, to examine the nature of the influence of chosen factors on the outcome of BPM in organizations within the clothing industry. Following the result of the reliability test, the modelling of the defined significant impact on the effective management of business processes in the clothing industry. Human resources play a significant role in improving organizational processes because of their engagement within the process $[38,39]$. That is why is created the last hypothesis: Perceptions and behaviour of human resources connected to issue of BPM significantly influence the establishment of effective BPM (H8). On the basis of assumed relationships among described factors above, the conceptual model, presented in figure 1 , is developed.

\section{RESULTS AND DISCUSSION}

Results of descriptive statistics offer a clear insight in the sample profile. The survey included a total of 508 employees in the clothing industry organizations, of which 245 (48.2\%) were employed in micro, small and medium-sized organizations, while 263 (51.8\%) were employed in large organizations. Production workers make up $69.9 \%$ of the sample. In regard to the age structure of employees, $14.8 \%$ are young, $70.1 \%$ are middle-aged and $15.2 \%$ are older employees. The survey covered $74.4 \%$ of female employees, while only $25.6 \%$ of male employees participated in the survey.

Results obtained on the basis of prepared questionnaire, before structural modelling and hypothesis testing, were firstly analysed and their reliability was evaluated. Cronbach's Alpha coefficient is useful in estimating the internal consistency of the reliability of a questionnaire containing a larger number of items [40]. Values of Cronbach's Alpha coefficients exceeding 0.7 are considered desirable and acceptable values [41]. The value of Cronbach's Alpha coefficient obtained in this study is given in table 2 .

On the basis of the calculated value of Cronbach's Alpha coefficient $(0.824)$ for the whole questionnaire, it is obviously that it may be used as a reliable instru-

Table 2

\begin{tabular}{|c|c|c|}
\hline \multicolumn{3}{|c|}{ DATA RELIABILITY } \\
\hline $\begin{array}{c}\text { Cronbach's } \\
\text { Alpha }\end{array}$ & $\begin{array}{c}\text { Cronbach's Alpha Based } \\
\text { on Standardized Items }\end{array}$ & $\begin{array}{c}\text { Number } \\
\text { of items }\end{array}$ \\
\hline 0.824 & 0.824 & 11 \\
\hline
\end{tabular}

problem is conducted using IBM SPSS AMOS program.

Structural Equation Modelling (SEM) provides answers on the relationships and impacts among the variables considered [42]. One of the basic steps of SEM is to evaluate the model based on quantitative indicators for assessing goodness of fit [43]. The recommended fit values of the model highlighted in [44] are presented in table 3 , in addition to the fit values of the model calculated in this research.

Table 3

SUGGESTED AND CALCULATED MODEL FIT PARAMETERS

\begin{tabular}{|l|c|c|}
\hline \multicolumn{1}{|c|}{ Indicators of model } & $\begin{array}{c}\text { Suggested } \\
\text { values }\end{array}$ & $\begin{array}{c}\text { Values from } \\
\text { model output }\end{array}$ \\
\hline $\mathrm{X}^{2} / \mathrm{df}$ & $\leq 3.00$ & 1.694 \\
\hline $\begin{array}{l}\text { Root mean square } \\
\text { error of approximation } \\
\text { (RMSEA) }\end{array}$ & $\leq 0.08$ & 0.037 \\
\hline $\begin{array}{l}\text { Root mean square } \\
\text { residual (RMR) }\end{array}$ & $\leq 0.05$ & 0.018 \\
\hline $\begin{array}{l}\text { Goodness of fit index } \\
\text { (GFI) }\end{array}$ & $\geq 0.9$ & 0.978 \\
\hline $\begin{array}{l}\text { Adjusted goodness of } \\
\text { fit (AGFI) }\end{array}$ & $\geq 0.9$ & 0.960 \\
\hline Normed fit index (NFI) & $\geq 0.9$ & 0.966 \\
\hline $\begin{array}{l}\text { Comparative fit index } \\
\text { (CFI) }\end{array}$ & $\geq 0.9$ & 0.986 \\
\hline
\end{tabular}

It can be noticed from the values presented in table 3 that all the parameters, read from the output after the model evaluation, were in accordance with the recommended fit values. Since all parameters were satisfied, the structural model with standardized estimates was developed, and, it is presented in figure 2 . From the derived model, presented in figure 2, it is possible to read the $\mathrm{R}^{2}$ value for the considered variable effective BPM in the clothing industry organizations, which is coded by the code BPM in the model. This value is 0.96 and, consequently, it means that the chosen predictor factors explain $96 \%$ of the variance of the considered endogenous variable. Table 4 


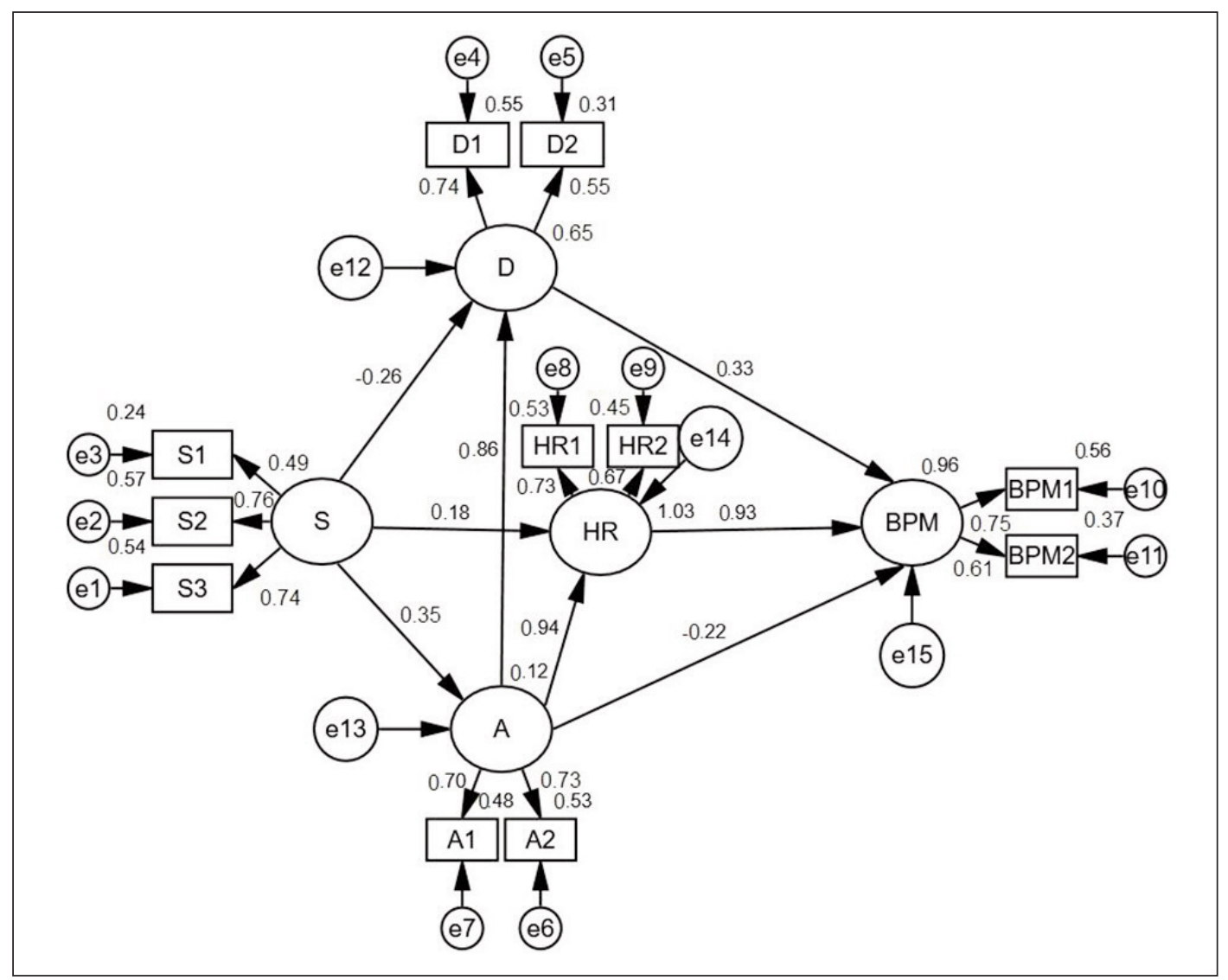

Fig. 2. Model of influences on efficient BPM in clothing industry organizations

presents the values that more closely explain the nature of the defined relationships and, they also show that impacts of the considered factors exist.

There are, according the results presented in table 4, significant influence between all the modelled elements, except one. Therefore, seven assumed possible impacts are statistically significant, and, among them six factors have a positive direction while one has a negative one. This observation stems from the insight into the values expressed in column C.R., and, in the value expressed in column $\mathrm{P}$, where it is assumed that the value of C.R. is significant if greater than or equal to 1.96 at $p \leq 0.05$ [45]. Therefore, it is noticeable that the implementation of activities that would be called primary doesn't have a direct impact on the BPM because the value is the value of C.R. less than the adopted limit value and $p$ value greater than 0.05 . Based on these values, hypothesis $\mathrm{H} 7$ is rejected. Among other influences, which are confirmed by the model, the strongest is in the relation between the primary activities of UPP and human resources within the clothing industry business processes with a standardized estimate value (b) of 0.940 and a significance of ${ }^{* * *}$, or less than 0.001 . The effect of active involvement of top management and the definition and documentation of process

\begin{tabular}{|l|c|c|c|c|c|}
\hline \multicolumn{7}{|c|}{ MODEL ESTIMATIONS } \\
\hline \multicolumn{1}{|c|}{ Hypothesized path } & Estimate & $\begin{array}{c}\text { Standardised } \\
\text { estimate }\end{array}$ & C.R. & P & Note \\
\hline H1 (S-D) & -0.245 & -0.263 & -3.834 & ${ }^{* * *}(<0.001)$ & Sig. \\
\hline $\begin{array}{l}\text { H2 (D-BPM) } \\
\text { *indirect (S-D-BPM) }\end{array}$ & 0.358 & 0.327 & 2.453 & 0.014 & $\begin{array}{l}\text { Sig. } \\
\text { Sig. }\end{array}$ \\
\hline H3 (S-A) & 0.355 & 0.348 & 5.373 & ${ }^{* * *}(<0.001)$ & Sig. \\
\hline H4 (S-HR) & 0.183 & 0.176 & 3.189 & 0.001 & Sig. \\
\hline H5 (A-HR) & 0.958 & 0.940 & 13.021 & ${ }^{* * *}(<0.001)$ & Sig. \\
\hline H6 (A-D) & 0.785 & 0.857 & 11.370 & ${ }^{* * *}(<0.001)$ & Sig. \\
\hline H7 (A-BPM) & -0.216 & -0.216 & -0.462 & 0.644 & Not sig. \\
\hline H8 (HR-BPM) & 0.916 & 0.934 & 2.347 & 0.019 & Sig. \\
\hline
\end{tabular}


roles, which were taken as priority activities, is not direct in relation to the effectiveness of BPM, but as the next strong influence is the link between the human resources element and the effective BPM, with $\beta=0.934$ and $p=0.019$, it is possible to consider the indirect effect of this element. $A$ third effect on strength, based on the value of $\beta=0.857$ and $p<0.001$, was observed in the path between the primary activity variables and the BPM dimension, with the assessment of the use of activities that would emerge as primary, such as those highlighted in this research, contributes to the better establishment of different dimensions that ultimately contribute to a more effective BPM. The contribution of the BPM dimensions to the effective BPM is moderate and positive $(\beta=0.857, p=0.014)$, and the hypothesis $\mathrm{H} 2$ is accepted on the basis that the measured indirect effect of the specific aspects of the clothing industry on the effective BPM which, through the BPM dimensions, is moderate and positive with the realized significance $p=0.001$. The influence of specificity, as a starting element of research, has also been demonstrated in the model. Relative to the BPM dimensions, this impact is negative and weak $(\beta=-0.263$, $p<0.001)$, relative to the primary activities positive and moderate $(\beta=0.348, p<0.001)$ and positive and weak relative to human resources in the BPM clothing industry organizations $(\beta=0.176, p=0.001)$. Thus, among the variables that mostly helps to explain the dependent variable - effective BPM - in the clothing industry organizations, two variables stand out: the BPM dimensions and the human resources.

\section{CONCLUSION}

The effect of the specific aspects of the clothing industry, the primary BPM activities, BPM dimensions and human resources within the BPM system to the effective BPM, as well as mutual influences of the chosen factors, are investigated by structural modelling. The applied approach allowed us to describe direct as well as indirect effects. It is noticed that the strongest impact on effective BPM, based on the results generated by the model, might be attributed to the HR factor. Thus, perceptions and behaviours of employees significantly influence the establishment of an effective BPM in clothing industry organizations. Although indirect, the effect of the specific aspects of the clothing industry on the establishment of BPM is also recognized in the model. Primary activities represent the only factor, of the variables examined by the research, that doesn't directly affect the establishment of an effective BPM.

The recognized impacts within the model are derived as the outcome of evaluation made by 508 employees in clothing industry organizations. Yet, a more comprehensive research is inevitable. Further research, for instance, could address in-depth examination of influential factors, the potential of indirect impacts and impact of indicators of each factor, and generating measures to strengthen BPM in clothing industry organizations.

\section{ACKNOWLEDGEMENTS}

The paper was prepared within the project TR 34023, which is supported by the Ministry of Education, Science and Technological Development of Republic of Serbia.

\section{REFERENCES}

[1] Urošević, S., Radosavljević, D., Stefanović, V., Đorđević, D., Kokeza, G., Multicriteria ranking of a job positions by ELECTRA methods in order to improce the analysis and conditions at work in companies in the textile industry, In: Industria Textila, 2017, 68, 5, 388-395, https://doi.org/IT.068.05.1378

[2] Mareš, D., The Key Factors in the Textile Industry, In: Acta VŠFS-ekonomické studie a analýzy, 2019, 13, 1, 61-78

[3] Cuc, S., Tripa, S., Redesign and upcycling-a solution for the competitiveness of small and medium-sized enterprises in the clothing industry, In: Industria Textila, 2018, 69, 1, 31-36, http://doi.org/10.35530/IT.069.01.1417

[4] Stefanović, V., Urošević, S., The impact of harmfulness in work process on safety and health of employed women with regard to the textile industry, In: Tekstilna industrija, 2019, 67, 3, 4-13

[5] Tudor, L., Change in textile and clothing industry, In: Industria Textila, 2018, 69, 1, 37-43, http://doi.org/ 10.35530/IT.069.01.1449

[6] Dobrosavljević, A., Managing the creative and labor-intensive business processes of the apparel industry, In: Tekstilna industrija, 2019, 67, 4, 58-66

[7] Tonelli, F., Demartini, M., Loleo, A., Testa, C., A novel methodology for manufacturing firms value modeling and mapping to improve operational performance in the industry 4.0 era, In: Procedia CIRP, 2016, 57, 122-127

[8] Kaniški, I., Vincek, I., Business processes as business systems, In: Tehnički glasnik, 2018, 12, 1, 55-61

[9] Fleacă, E., Purcărea, A.A., Raising the competitiveness of Romanian enterprises acting in textile industry based on process management modeling, In: Industria Textila, 2014, 65, 1, 47-52

[10] Havur, G., Cabanillas, C., Mendling, J., Polleres, A., Automated resource allocation in business processes with answer set programming, In: International Conference on Business Process Management, Springer, Cham, 2016, 191-203

[11] Księżak, P., The CSR challenges in the clothing industry, In: Journal of Corporate Responsibility and Leadership, 2016, 3, 2, 51-65

[12] Taplin, I. M., Winterton, J., Winterton, R. Understanding labour turnover in a labour intensive industry: evidence from the British clothing industry, In: Journal of Management Studies, 2003, 40, 4, 1021-1046 
[13] Nemeša, I., Automatizovani sistemi za rezanje tekstila laserom, In: Tekstilna industrija, 2018, 66, 4, 52-57

[14] Şen Kılıç A. (2019). Comparison of Cad and Manual System Efficiency In Pre-Production Preparation Process, In: Tekstil ve Konfeksiyon, 2019, 29, 1, 67-77

[15] Antić, S., Ilić, A., Đorđević, S., Petrović, D., Analysis of the defined BlockBuffer parameters influence in computer making of pattern cutting images, In: Tekstilna industrija, 2018, 66, 4, 45-51

[16] Gašović, M., Ćurčić, N., Efekti marketinga i dizajna primenom CAD sistema u kompanijama-proizvođačima odeće, In: Vojno delo, 2018, 70, 6, 309-320

[17] Dimitrijević, D., Adamović, Ž., Urošević., S., Prokopović, B., Proces generisanja modela MSP - Participacija $i$ benefiti kompjuterskog modelovanja (2. deo), In: Tekstilna industrija, 2019, 67, 1, 39-50

[18] Eraydin, A., Erendil, A., The role of female labour in industrial restructuring: new production processes and labour market relations in the Istanbul clothing industry, In: Gender, Place and Culture: A Journal of Feminist Geography, 1999, 6, 3, 259-272

[19] Kucera, D., Tejani, S., Feminization, defeminization, and structural change in manufacturing, In: World Development, 2014, 64, 569-582

[20] Armistead, C., Machin, S., Implications of business process management for operations management, In: International Journal of Operations \& Production Management, 1997, 17, 9, 886-898

[21] Aagesen, G., Krogstie, J., BPMN 2.0 for modeling business processes, In: Handbook on Business Process Management 1, Springer, Berlin, Heidelberg, 2015, 219-250

[22] Glavan, L.M., Upravljanje poslovnim procesima u poduzećima Republike Hrvatske, In: Business and Economics Review, 2011, 31, 1, 105-125

[23] Schönig, S., Cabanillas, C., Jablonski, S., Mendling, J., Mining the organisational perspective in agile business processes, In Enterprise, Business-Process and Information Systems Modeling, Springer, Cham, 2015, 37-52

[24] Lindsay, A., Downs, D., Lunn, K., Business processes-attempts to find a definition, In: Information and software technology, 2003, 45, 15, 1015-1019

[25] Grover, V., Teng, J., Segars, A.H., Fiedler, K., The influence of information technology diffusion and business process change on perceived productivity: The IS executive's perspective, In: Information \& Management, 1998, 34, 3, 141-159

[26] Reijers, H., Design and Control of Workflow Precesses: Business Process Management for the Service Industry, In: Springer-Verlag Berlin, 2003

[27] Meidan, A., García-García, J.A., Escalona, M.J., Ramos, I., A survey on business processes management suites, In: Computer Standards \& Interfaces, 2017, 51, 71-86

[28] Daines III, J., Re-engineering archives: Business Process Management (BPM) and the quest for archival efficiency. In: The American Archivist, 2011, 74, 1, 123-157

[29] Gazova, A., Papulova, Z., Papula, J., The application of concepts and methods based on process approach to increase business process efficiency, In: Procedia Economics and Finance, 2016, 39, 197-205

[30] Ponsignon, F., Smart, P. A., Maull, R. S., (2012). Process design principles in service firms: Universal or context dependent? A literature review and new research directions, In: Total Quality Management \& Business Excellence, 2012, 23, 11-12, 1273-1296

[31] Nezhad, H. R. M., Akkiraju, R., Towards cognitive BPM as the next generation BPM platform for analytics-driven business processes, In: International Conference on Business Process Management, Springer, Cham, 2014, 158-164

[32] McCormack, K., Business process orientation: Do you have it?, In: Quality Progress, 2001, 34, 1, 51-58

[33] Škrinjar, R., Trkman, P., Increasing process orientation with business process management: Critical practices', In: International Journal of Information Management, 2013, 33, 48-60

[34] Bosilj Vukšić, V., Hernaus, T., Kovačić, A., Upravljanje poslovnim procesima - organizacijski i informacijski pristup, In: Školska knjiga, Zagreb, 2008

[35] Vlahovic, N., Milanovic, L., Škrinjar, R. Turning points in business process orientation maturity model: an east European survey, In: WSEAS transactions on business and economics, 2010, 7, 1, 22-32

[36] Buh, B., Kovačič, A., Indihar Štemberger, M., Critical success factors for different stages of business process management adoption - a case study, In: Economic Research-Ekonomska Istraživanja, 2015, 28, 1, 243-257

[37] Hernaus, T., Vuksic, V.B., Štemberger, M.I., How to go from strategy to results? Institutionalising BPM governance within organisations, In: Business Process Management Journal, 2016, 22, 1, 173-195

[38] Abdolvand, N., Albadvi, A., Ferdowsi, Z., Assessing readiness for business process reengineering, In: Business Process Management Journal, 2008, 14, 4, 497-511

[39] Zairi, M., Business process management: a boundaryless approach to modern competitiveness, In: Business process management journal, 1997, 3, 1, 64-80

[40] Sun, W., Chou, C.P., Stacy, A.W., Ma, H., Unger, J., Gallaher, P., SAS and SPSS macros to calculate standardized Cronbach's alpha using the upper bound of the phi coefficient for dichotomous items, In: Behavior research methods, 2007, 39, 1, 71-81

[41] Taber, K.S., The use of Cronbach's alpha when developing and reporting research instruments in science education. In: Research in Science Education, 2018, 48, 6, 1273-1296 
[42] Srhoj, S., Batarelo Kokić, I., Krišto, T., U potrazi za inovacijama: medijacijska uloga orijentacije učenju u odnosu odrednica poduzetničke klime i proizvodno-uslužnih inovacija, In: Poslovna izvrsnost: znanstveni časopis za promicanje kulture kvalitete i poslovne izvrsnosti, 2017, 11, 1, 9-36

[43] Fan, Y., Chen, J., Shirkey, G., John, R., Wu, S.R., Park, H., Shao, C. Applications of structural equation modeling (SEM) in ecological studies: an updated review, In: Ecological Processes, 2016, 5, 1, 19

[44] Wu, J.H., Wang, S.C., Lin, L.M., Mobile computing acceptance factors in the healthcare industry: A structural equation model, In: International journal of medical informatics, 2007, 76, 1, 66-77

[45] Teo, T., Tsai, L.T., Yang, C.C., Applying structural equation modelling (SEM) in educational research: An introduction, In: Application of structural equation modeling in educational research and practice, Brill Sense, 2013, 1-21

\section{Authors:}

ANDREA DOBROSAVLJEVIĆ, SNEŽANA UROŠEVIĆ, MILOVAN VUKOVIĆ, NADA ŠTRBAC

University of Belgrade, Technical Faculty in Bor, Engineering Management Department, Vojske Jugoslavije 12, 19210, Bor, Serbia,

\section{Corresponding author:}

SNEŽANA UROŠEVIĆ

e-mail: surosevic@tfbor.bg.ac.rs, snezanaur@gmail.com 